Fusarium Wilt Epidermic and its affects on Trading

\title{
Elliot Madonsela*
}

Department of Agriculture, Tshwane University of Technology, South Africa

*Corresponding Author: Elliot Madonsela, Department of Agriculture, Tshwane University of Technology, South Africa.

Received: July 30, 2019; Published: August 14, 2019

DOI: $10.31080 /$ ASAG.2019.03.0613

Banana (Musa spp.) is probably one of the world's important crops in fruit. The year 2011, the combined world production was about 145 million tons with a gross production of 44 billion US dollars. Almost $15 \%$ of total production reaches international market and almost all of them are Cavendish subgroup cultivar. The remaining $85 \%$ is sold in local markets of which $28 \%$. Despite common behavior that banana grows in humid trpics, it has been found to be important in the arid subtropical Middle East . By 12century all of north Africa had bananas, Middle easterns called it "musa" Arabs called it "mauz"

Panamawit aka fusarium wilt of Musa spp. Has been a destructive issue for more than a century now. race 1 of the pathogen was fusarium oxysrum $f$. sp. cubense (foc) which was the cause of the failed first export trades of banana that were based on Gros Michel cultivar. Now recently Tropical race 4 (TR4) plagues Cavendish. TR4 was first confirmed in Jordan 2013 but may have been present since 2005 but maybe it wasnt virulent enough or number were below noticable. The outbreak was the first recorded for panama wilt in the Middle East, it represented the expanding distribution of TR4 pathogens which were restricted to the Far East. Its arrival to Jordan is unknown.

Apparently the common name reminisces the extensive damage it caused in export plantations in Central American countries from the 1800 s by 1900 s the disease had spread to tropical America, the Caribbean and Western Africa destroying 40000ha of Gros Michel cultivar. These epidemics played a significant role in the conversion of cultivar to Cavendish subgroup.

Fusarium oxysporum f. sp. Cubense is a member of the F. oxysporum species complex. This means that plant plant pathogens often exhibit considerable host specificity, a single pathogenic is formed, the formae speciales affect a single of limited set of host. Although better understaning of FOC variation is needed it seems TR4 is comprised of a single clone of the pathogen vegetative compatibility group. A diagnostic procedure was developed relying on the homogeneous nature of the pathogen to identify new destructive outbreaks.

\section{Options for disease management}

Expert advice from a field plant Pathogenist is needed, consult early.

- Biological control: Mycorrhizae, Trichoderma, bacteria, Actinomycetes.

- Chemical control: Fungicide dripping, surface sterilants for implements, soil fumigation, plant activators.

\section{Cultural control}

- $\quad$ Clean planting material (tissue culture),

- Sanitary and phytosanitary activities

- Crop rotation and fallow periods

- $\quad$ Soil fixing eg. Ph, nitrogen etc

- $\quad$ Flood fallowing and bio-fumigants

- $\quad$ Suprressiive soil properties

- $\quad$ Proper irrigation

- $\quad$ Field fencing limiting human vectors

IDM combination

- $\quad+$ mixed cropping systems

- $\quad+$ plant resistance and soil fixing

- $\quad$ + fumigation and use biological control

Volume 3 Issue 9 September 2019

(C) All rights are reserved by Elliot Madonsela. 